\title{
Seven years of measurements of aerosol scattering properties, near the surface, in the southwestern Iberia Peninsula
}

\author{
S. N. Pereira ${ }^{1}$, F. Wagner $^{1}$, and A. M. Silva ${ }^{1,2}$ \\ ${ }^{1}$ Évora Geophysics Centre, Évora, Portugal \\ ${ }^{2}$ Physics Department of the University of Évora, Évora, Portugal
}

Received: 19 April 2010 - Published in Atmos. Chem. Phys. Discuss.: 1 June 2010

Revised: 19 November 2010 - Accepted: 22 November 2010 - Published: 3 January 2011

\begin{abstract}
Aerosol scattering properties, near the surface (at about $10 \mathrm{~m}$ height), were measured during a period of seven years (2002-2008) at Évora, Portugal. The average (and median) scattering and backscattering coefficients, at the wavelength of $550 \mathrm{~nm}$, were found to be $42.5 \mathrm{Mm}^{-1}\left(29.9 \mathrm{Mm}^{-1}\right)$ and $5.9 \mathrm{Mm}^{-1}\left(4.4 \mathrm{Mm}^{-1}\right)$, respectively. Also, the average and median scattering Ångström exponent (1.4 and 1.5) indicate that scattering was, in general, dominated by submicrometer particles. Both seasonal and daily cycles are shown, which were related to local production and transport of particles from elsewhere. Summer and winter average values of the scattering coefficient, at the wavelength of $550 \mathrm{~nm}$ (47 and $54 \mathrm{Mm}^{-1}$, respectively), correspond to a significant increase in the aerosol particle concentration when compared with spring and fall (35 and $37 \mathrm{Mm}^{-1}$, respectively). Also, the average increase in the Ångström exponent for summer and winter seasons is consistent with the input of sub-micrometer particles from anthropogenic origin in winter and forest fires in summer.

Back-trajectory analysis indicated that the site was regularly under the influence of air masses from the Atlantic area, with low particle loads (low scattering coefficients), but as the influence of transport from the continent (Iberia Peninsula) increased, the aerosol particle load was observed to increase as well as the relative importance of fine particles over coarse ones, approaching the features observed at the site during European air masses influence.
\end{abstract}

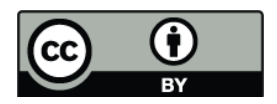

Correspondence to: S. N. Pereira (sergiopereira@uevora.pt)

\section{Introduction}

The assessment of aerosols direct effect on climate (due to their interaction with solar and terrestrial radiation, via scattering and absorption processes) requires quantitative information on the optical properties of atmospheric aerosols. The multiplicity of aerosol sources, transformation processes and sinks is responsible for the large variability in their properties both in space and time; this means that in a certain time the global aerosol concentration field is complex and at a certain place aerosol properties may also be highly variable in time. Under these circumstances, long-term measurements of aerosol properties at different locations are essential for better characterising both for the aerosol field and climatology, providing aerosol data to be included into global climate models in order to decrease the uncertainties of climate forcing estimations.

Previous studies on aerosol properties at the surface (and in the column), based on measurements carried out on this region have shown that the aerosol load could be considered, in general, as moderate to low. Moreover, the influence of long range transported aerosols from forest fires in summer and of desert dust from the Sahara region (mainly at high altitudes) or the influence of anthropogenic pollution from Europe and the Iberian Peninsula itself could also be clearly detected. However, these studies where based on measurements carried out during short periods; during ACE-2 (JuneJuly 1997) and CAPEX and DARPO (May-June 2006) campaigns (Carrico et al., 2000; Müller et al., 2002; Silva et al., 2002, 2003; Ansmann et al., 2002; Wagner et al., 2009); summer periods (Elias et al., 2006); one year period (Pereira et al., 2008). For the first time a long term dataset of surface in situ measurements of the aerosol scattering properties is

Published by Copernicus Publications on behalf of the European Geosciences Union. 
Table 1. Time evolution of the calibration constants, $\mathrm{K} 2$ and $\mathrm{K} 4\left(\mathrm{~m}^{-1}\right)$, at three wavelengths.

\begin{tabular}{lllllll}
\hline Time & K2 $450 \mathrm{~nm}$ & $\mathrm{~K} 2550 \mathrm{~nm}$ & $\mathrm{~K} 2700 \mathrm{~nm}$ & $\mathrm{~K}_{450 \mathrm{~nm}}$ & $\mathrm{~K} 4550 \mathrm{~nm}$ & $\mathrm{~K} 4700 \mathrm{~nm}$ \\
\hline $07 / 2001$ & $4.166 \times 10^{-3}$ & $4.040 \times 10^{-3}$ & $4.056 \times 10^{-3}$ & $5.017 \times 10^{-1}$ & $5.049 \times 10^{-1}$ & $5.405 \times 10^{-1}$ \\
$12 / 2002$ & $4.213 \times 10^{-3}$ & $4.036 \times 10^{-3}$ & $4.554 \times 10^{-3}$ & $5.000 \times 10^{-1}$ & $5.060 \times 10^{-1}$ & $5.900 \times 10^{-1}$ \\
$12 / 2004$ & $5.042 \times 10^{-3}$ & $4.879 \times 10^{-3}$ & $4.660 \times 10^{-3}$ & $5.070 \times 10^{-1}$ & $5.160 \times 10^{-1}$ & $5.320 \times 10^{-1}$ \\
$02 / 2006$ & $5.573 \times 10^{-3}$ & $5.280 \times 10^{-3}$ & $5.239 \times 10^{-3}$ & $5.254 \times 10^{-1}$ & $5.253 \times 10^{-1}$ & $5.145 \times 10^{-1}$ \\
\hline \multicolumn{7}{l}{ The nephelometer had a break down and some electronics were substituted } \\
\hline $01 / 2007$ & $8.635 \times 10^{-3}$ & $8.472 \times 10^{-3}$ & $8.535 \times 10^{-3}$ & $5.245 \times 10^{-1}$ & $5.233 \times 10^{-1}$ & $4.511 \times 10^{-1}$ \\
$03 / 2008$ & $9.620 \times 10^{-3}$ & $9.340 \times 10^{-3}$ & $9.550 \times 10^{-3}$ & $5.180 \times 10^{-1}$ & $5.230 \times 10^{-1}$ & $4.530 \times 10^{-1}$ \\
$01 / 2009$ & $1.053 \times 10^{-2}$ & $1.018 \times 10^{-2}$ & $9.943 \times 10^{-3}$ & $5.249 \times 10^{-1}$ & $5.115 \times 10^{-1}$ & $4.562 \times 10^{-1}$ \\
\hline
\end{tabular}

used to generate aerosol climatology for a continental rural region of southwestern Europe. The multi-spectral measurements of scattering and backscattering coefficients provided by a nephelometer are useful for quantifying the aerosol load and also for a distinction of aerosol events, namely those dominated by accumulation mode particles or coarse mode particles.

\section{Measurements and methodology}

\subsection{Site description}

Évora $\left(38.5^{\circ} \mathrm{N}, 7.9^{\circ} \mathrm{W}, 300 \mathrm{~m}\right.$ a.s.1., $\sim 60000$ inhabitants $)$ is a small Portuguese city located in the southwestern part of the Iberian Peninsula. The distance both to the Atlantic coast and to the main populated and industrial area of greater Lisbon is more than $100 \mathrm{~km}$. There are no polluting industries in the region, therefore, the local anthropogenic sources are mainly related to traffic as well as wood burning during the colder winter period; occasionally it may suffer the influence of the long range transported anthropogenic aerosols from major populated and industrial regions in the Iberian Peninsula or Central Europe, or natural aerosols from the Saharan desert.

\subsection{Equipment and dataset}

A three wavelength integrating nephelometer (TSI-3563, TSI Inc., St Paul, Minnesota, USA) measured the aerosol scattering coefficients, $\sigma_{\mathrm{sp}}(\lambda)$, and backscattering coefficients, $\sigma_{\text {bsp }}(\lambda)$, at the wavelengths $\lambda=450,550$ and $700 \mathrm{~nm}$. These data were recorded with a temporal resolution of $5 \mathrm{~min}$. The aerosol was sampled through a $\mathrm{PM}_{10}$ sampling head located at about $10 \mathrm{~m}$ above the ground, selecting particles with aerodynamic diameter smaller than $10 \mu \mathrm{m}$. The flow rate was fixed at $30 \mathrm{lmin}^{-1}$. The scattered light in the angular range of $7-170^{\circ}$ was measured and the aerosol scattering coefficient was derived after the correction for the calculated molecular scattering and for the angular truncation and the non-Lambertian errors (Anderson and Ogren, 1998); the light scattered from $90-170^{\circ}$ (backscattered signal) was also measured and the aerosol backscattering coefficient was derived. The instrument was calibrated about once a year using $\mathrm{CO}_{2}$ as high span gas and filtered dry air as low span gas; zero signal was measured once an hour. The record of calibration constants is provided in Table 1 .

The Ångström exponent, $\alpha$, represents the wavelength dependence of $\sigma_{\mathrm{sp}}(\lambda)$ and can be related to a mean size of the particles. It was calculated using the 450 and $700 \mathrm{~nm}$ channels as follows:

$\alpha=-\frac{\log \left(\sigma_{\mathrm{sp}}(700)\right)-\log \left(\sigma_{\mathrm{sp}}(450)\right)}{\log (700)-\log (450)}$

Daily back-trajectories ending at Évora monitoring site, at 500 ma.s.1 ( $200 \mathrm{ma.g.1})$, were calculated using the Hybrid Single-Particle Lagrangian Integrated Trajectory Model (HYSPLIT) (Draxler and Rolph, 2003) to interpret data in terms of the aerosol origins; the altitude was selected to represent the air sampled by the Nephelometer. Temperature, relative humidity and wind speed and direction were also measured at the site. Hourly averaged data (about 47000 measurements - about $80 \%$ of the overall measurements from April 2002 to December 2008) were used and longer term statistics were based on these hourly values.

\subsubsection{Relative humidity correction}

Relative humidity $(\mathrm{RH})$ is one of the factors influencing the amount of scattered solar radiation by aerosol particles (Horvath, 1996). If RH increases, then hydrophilic atmospheric particles tend to grow, due to water uptake, and scatter more light. The light scattering humidification factor, $\mathrm{f}(\mathrm{RH})$, quantifies the influence of $\mathrm{RH}$ on $\sigma_{\mathrm{sp}}(\lambda)$. It is the ratio between $\sigma_{\mathrm{sp}}(\lambda)$ at high and low $\mathrm{RH}$ values. The low $\mathrm{RH}$ is usually considered to be lower than $40 \%$ (Kotchenruther et al., 1999; Koloutsou-Vakakis et al., 2001; Magi and Hobbs, 2003; Targino et al., 2005).

$f(\mathrm{RH})=\frac{\sigma_{\mathrm{sp}}(\lambda)_{\text {high } \mathrm{RH}}}{\sigma_{\mathrm{sp}}(\lambda)_{\text {low } \mathrm{RH}}}$ 


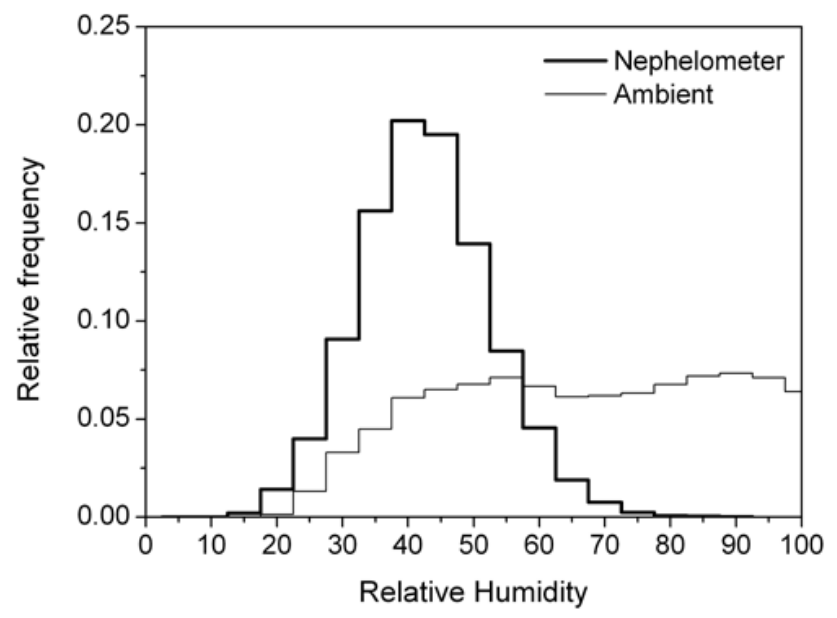

Fig. 1. Relative frequency distributions of measured ambient RH at the site and measured RH inside the nephelometer's sensing chamber.

In order to assess the temporal variation of the scattering coefficients, the influence of $\mathrm{RH}$ on $\sigma_{\mathrm{sp}}(\lambda)$ variations has to be eliminated.

Figure 1 shows the relative frequency distributions of measured ambient RH values at the monitoring site and measured RH values inside the nephelometer's optical chamber. The difference between the two measured RH values is clear: the lower and less variable RH values measured inside the nephelometer are due to the heating by the lamp in the measuring sensing chamber, whereas the ambient RH values comprises of a large range of values. The RH values of the sampled aerosol are constrained mainly in the range of 30-50\%, with an average of $40 \%$ and standard deviation (SD) of $10 \%$. Therefore, the measurements of $\sigma_{\mathrm{sp}}(\lambda)$ were essentially performed with the aerosol under dry conditions and the RH corrections are expected to have minor influence in the overall results that follow in the next sections. This hypothesis was confirmed as the difference between the corrected and noncorrected values was found to be insignificant because only a few data were taken under non-dry conditions. In spite of that, corrected values were still used.

Due to the lack of measured $f(\mathrm{RH})$ for the sampling site, functions from the literature, corresponding to different aerosol types, were used. The prevailing aerosol population at the site is of a continental type. Anthropogenic aerosols from local or long distant sources, as well as smoke aerosols from forest fires and desert dust from Africa, were also present. The $f(\mathrm{RH})$ functions were chosen according to these aerosol types; we then distinguished between measurements made under clean/background continental conditions (the most common situation) and under perturbed conditions. The separation between different aerosol types was done by using threshold values based on absolute values of the spectral scattering coefficients and of the Ångström expo- nent; a previous classification scheme by Elias et al. (2006) was based only in a summer period of measurements and half day averages were considered (instead of hourly), therefore, an improved classification criteria was used. The threshold values are provided in Table 2. The correction functions for clean/background conditions were based on Magi and Hobbs (2003). The correction functions for pollution data were based on Carrico et al. (2000) whose results regard "a continental site influenced by aerosol with anthropogenic origin". They are very similar to the ones obtained by Koloutsou-Vakakis et al. (2001) for polluted aerosol and Magi and Hobbs (2003) for biomass burning plumes. Desert dust aerosols were considered as being hydrophobic (Carrico et al., 2003; Fierz-Schmidhauser et al., 2009), therefore, no correction for RH was applied when it dominated the aerosol population.

\section{Results and discussion}

\subsection{General features}

Here, we present some basic statistics concerning the whole period (2002-2008) in order to characterise the aerosol optical properties in the region under study. Figure 2 shows the relative frequency distributions for $\sigma_{\mathrm{sp}}(550), \alpha$ and $\sigma_{\mathrm{bsp}}(550)$ hourly values. The frequency distributions are characterised by long right tails for $\sigma_{\mathrm{sp}}(\lambda)$ and $\sigma_{\mathrm{bsp}}(\lambda)$ while $\alpha$ is left skewed. It has been shown previously (Deacon et al.,1997; Artiñano et al., 2001; Gerasopoulos et al., 2003; Freitas, 2006; Pereira et al., 2008) that the frequency distribution of scattering coefficients (or other aerosol extensive properties) can be well described by a log-normal distribution. Therefore, median values better illustrate the average conditions than the mean by decreasing the contribution of the most extreme events; this is also true for describing the average conditions of the Ångstrom exponent, $\alpha$, whose frequency distribution is also skewed. The median, mean, geometric mean, standard deviation, $5 \%$ percentile, $\mathrm{P} 5$, and $95 \%$ percentile, P95, are presented in Table 3. Log-normal parameters (modal value and geometrical standard deviation, GSD) derived for $\sigma_{\mathrm{sp}}(\lambda)$ and $\sigma_{\mathrm{bsp}}(\lambda)$ distributions are also shown.

Hourly values of $\sigma_{\mathrm{sp}}(\lambda)$ were found to be highly variable, ranging from values close to the detection limit up to a few extreme measurements above $2000 \mathrm{Mm}^{-1}$ (about $250 \mathrm{Mm}^{-1}$ in the case of $\sigma_{\mathrm{bsp}}(\lambda)$ ) recorded during the forest fire plumes in August 2005 (not shown in Fig. 2 for better resolution). $98 \%$ of the $\sigma_{\mathrm{sp}}(\lambda)$ values were in the range of $8-250 \mathrm{Mm}^{-1}$, but most of this percentage is below $60 \mathrm{Mm}^{-1}(\sim 80 \%)$. The median and mean values of $\sigma_{\mathrm{sp}}(550)$ are 30 and $42 \mathrm{Mm}^{-1}$, respectively, for the whole period. In the case of $\sigma_{\mathrm{sp}}(550)$ its median and mean values are 4.4 and $5.9 \mathrm{Mm}^{-1}$, respectively. The median and mean values of the Angström exponent (1.5 and 1.4, respectively) imply that the scattering is, in general, dominated by submicron particles. About $60-70 \%$ 

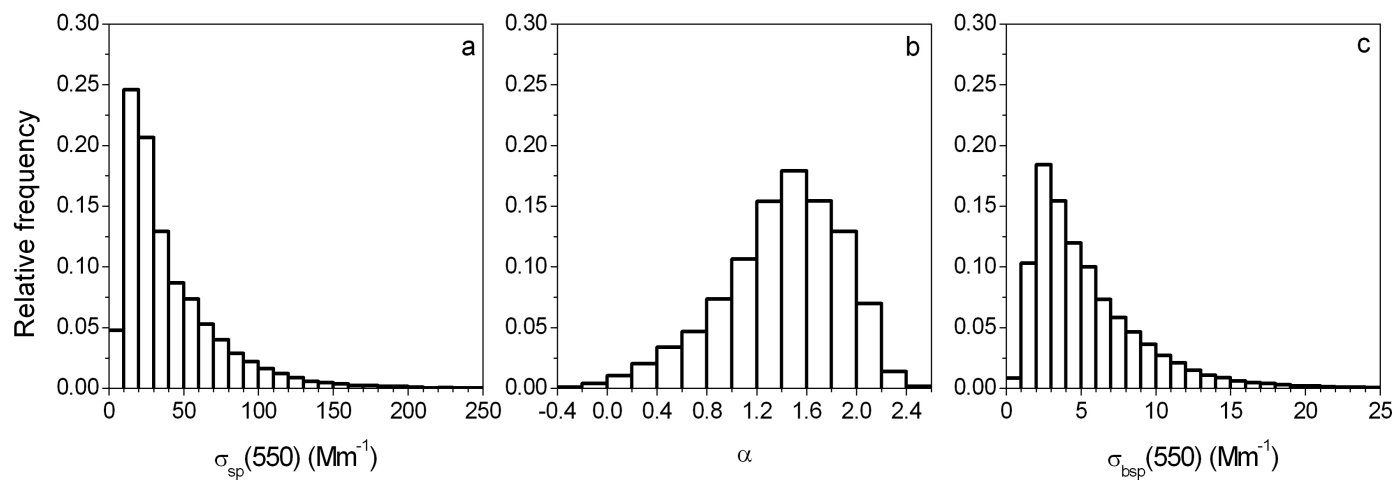

Fig. 2. Relative frequency distributions of (a) $\sigma_{\mathrm{sp}}(550)$, (b) $\alpha$ and (c) $\sigma_{\mathrm{sp}}(550)$ hourly values $\left(\mathrm{N} \sim 47000\right.$ and bin size of $10 \mathrm{Mm}^{-1}, 0.2$ and $1 \mathrm{Mm}^{-1}$, respectively). Values of $\sigma_{\mathrm{sp}}(550)>250 \mathrm{Mm}^{-1}$ and $\sigma_{\mathrm{bsp}}(550)>25 \mathrm{Mm}^{-1}$ (less than 100 hourly values) are not shown for better resolution.

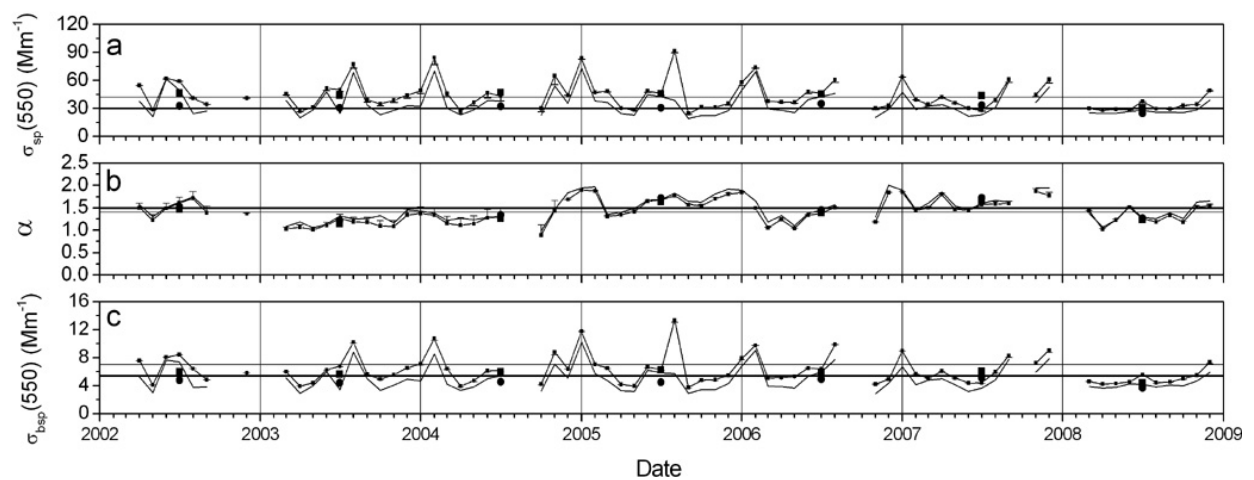

Fig. 3. Time series of mean (line with symbol) and median (line without symbol) monthly values of (a) $\sigma_{\mathrm{sp}}(550)$, (b) $\alpha$ and (c) $\sigma_{\mathrm{bsp}}(550)$. The error bars reflect the drift of the calibration constants and are added to the mean values. Annual values are represented by the black symbols (square for annual average and circle for annual median). Average (solid thin line) and median (solid thick line) values for the whole period are also depicted as horizontal lines.

Table 2. Used criteria for different aerosol types in terms of spectral scattering coefficients and Ångström exponent.

\begin{tabular}{ll}
\hline Aerosol type & Measured optical properties \\
\hline Clean/background & $\sigma_{\mathrm{sp}}(450)<60 \mathrm{Mm}^{-1}$ (any $\left.\alpha\right)$ \\
Pollution and Forest fires & $\sigma_{\mathrm{sp}}(450)>60 \mathrm{Mm}^{-1}(\alpha>1)$ \\
Desert dust & $\sigma_{\mathrm{sp}}(700)>30 \mathrm{Mm}^{-1}(\alpha<1)$ \\
\hline
\end{tabular}

of the light is scattered by sub-micrometer particles for an $\alpha$ of 1.5 (see Carrico et al., 1998, 2000; Sheridan et al., 2001; Quinn et al., 2002; Doherty et al., 2005).

These results are now briefly compared with other longterm measurements performed at other sites in the southern European region (see Table 4). These areas were observed to be influenced by local or transported continental pollution (besides desert dust) and present significantly higher average values of the scattering coefficient when compared with the ones obtained for Évora and presented in this work.
As already stated above, on the one hand Évora is a small city with low to moderate aerosol anthropogenic influence; on the other hand, being located in the southwestern European sector, is under the regular influence of Atlantic clean air masses, which contribute to lower aerosol concentrations levels, as previously observed (see e.g., Pereira et al., 2008; Lyamani et al., 2010).

\subsection{Temporal variations}

\subsubsection{Annual cycle}

Median and mean monthly values of $\sigma_{\mathrm{sp}}(550), \alpha$ and $\sigma_{\text {bsp }}(550)$ for the period of 2002-2008 are shown in the time series of Fig. 3. Figure 4 contains the yearly cycle as a function of both the month and season considering all the measurements for each month or season (as defined in Table 5). In both figures, error bars reflecting the drift of the calibration constants are included. The drift is less than $10 \%$ per year. This drift has a higher influence on shorter-term observations, e.g., when comparing monthly values of the 

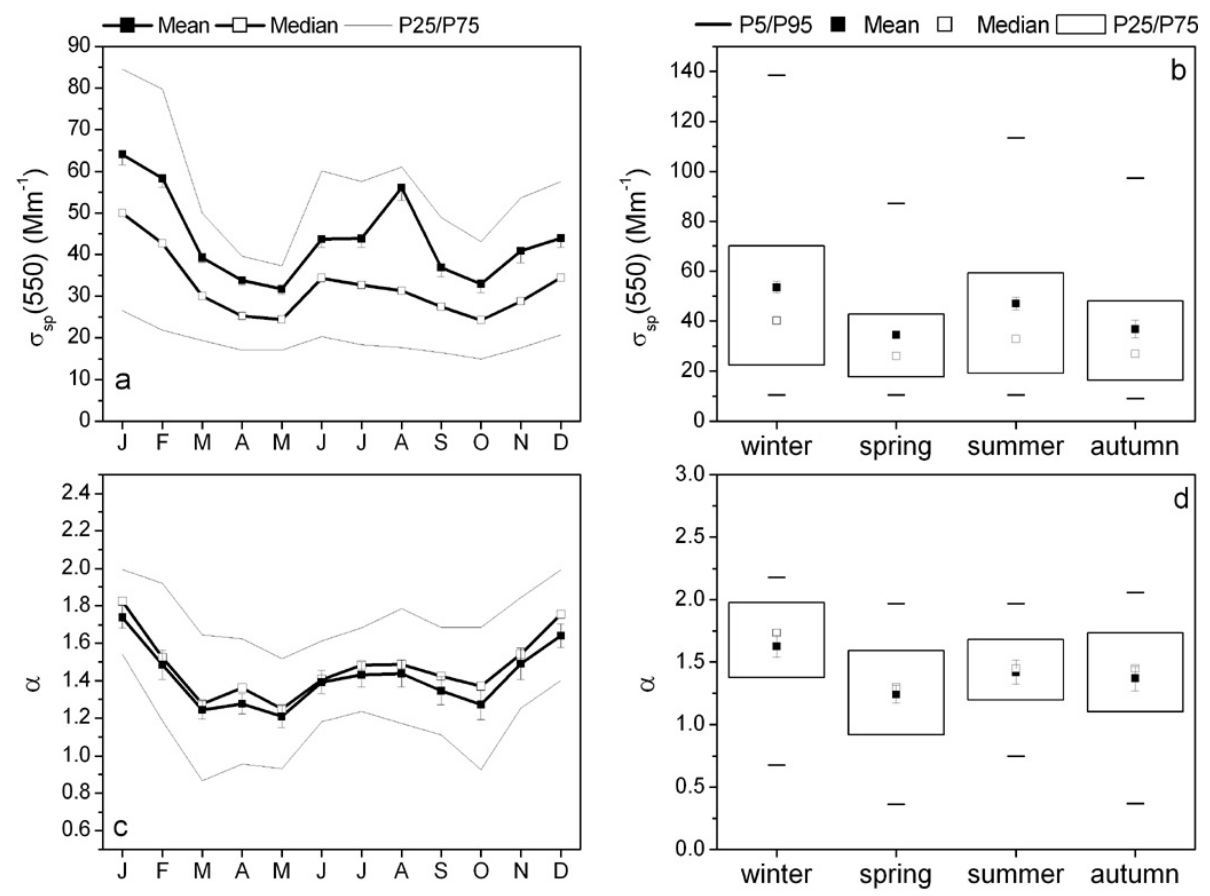

Fig. 4. Annual cycle of mean and median values of $\sigma_{\mathrm{sp}}(550)$ (a and $\left.\mathbf{b}\right)$ and $\alpha$ (c and $\mathbf{d}$ ) as a function of the month and season. The error bars reflect the drift of the calibration constants and are added to the mean values. The respective quartiles (P25 and P75) are also shown. In the case of the box charts, P5 and P95 are also included.

Table 3. Basic statistical parameters of $\sigma_{\mathrm{sp}}(\lambda), \sigma_{\mathrm{bsp}}(\lambda)$ and $\alpha$ for the period of 2002-2008. The latter doesn't have GSD because its frequency distribution is not log-normal.

\begin{tabular}{lllllllll}
\hline Parameter & Median & Mean & SD & P5 & P95 & Mode & $\begin{array}{l}\text { Geometric } \\
\text { Mean }\end{array}$ & GSD \\
& & & & & & & \\
\hline$\sigma_{\text {sp }}(450)\left(\mathrm{Mm}^{-1}\right)$ & 40.5 & 57.5 & 64.1 & 13.1 & 150.1 & 22.2 & 42.2 & 2.2 \\
$\sigma_{\text {sp }}(550)\left(\mathrm{Mm}^{-1}\right)$ & 29.9 & 42.5 & 45.9 & 10.1 & 109.9 & 19.9 & 31.6 & 2.1 \\
$\sigma_{\text {sp }}(700)\left(\mathrm{Mm}^{-1}\right)$ & 21.5 & 29.9 & 30.0 & 7.5 & 75.9 & 11.6 & 22.8 & 2.1 \\
$\sigma_{\text {bsp }}(450)\left(\mathrm{Mm}^{-1}\right)$ & 5.4 & 7.0 & 6.9 & 1.9 & 16.6 & 5.5 & 5.5 & 2.0 \\
$\sigma_{\text {bsp }}(550)\left(\mathrm{Mm}^{-1}\right)$ & 4.4 & 5.9 & 5.7 & 1.58 & 13.3 & 2.1 & 4.5 & 1.9 \\
$\sigma_{\text {bsp }}(700)\left(\mathrm{Mm}^{-1}\right)$ & 3.7 & 4.8 & 4.7 & 1.3 & 11.1 & 2.0 & 3.8 & 1.9 \\
$\alpha$ & 1.5 & 1.4 & 0.5 & 0.5 & 2.1 & 1.4 & - & - \\
\hline
\end{tabular}

same year as could be done in Fig. 3, but has a negligible impact on a seven year average (due to regular recalibrations) as included in Fig. 4.

Statistical information is summarized in Tables 5a, b and $\mathrm{c}$, respectively, for $\sigma_{\mathrm{sp}}(550), \alpha$ and $\sigma_{\mathrm{bsp}}(550)$. Hourly values were always used in the calculations of all statistical parameters. Regarding Fig. 3, the monthly median values of $\sigma_{\mathrm{sp}}(550)$ range from 19 to $73 \mathrm{Mm}^{-1}$ (mean values range from 23 to $92 \mathrm{Mm}^{-1}$ ). Only less than one quarter of these values (16 in 71 months) are higher than $40 \mathrm{Mm}^{-1} ; 14$ of these $16 \sigma_{\mathrm{sp}}(550)$ monthly values were recorded during winter and summer periods but the highest ones $\left(70-73 \mathrm{Mm}^{-1}\right)$ where recorded during the colder season. Monthly median values of $\alpha$ vary between 1.0 and 2.0. Moreover, the corresponding monthly median values for the 16 months, referred above, are the highest, ranging between 1.5 and 2.0 (3 exceptions). In contrast, the set of months with the lower monthly median values of $\sigma_{\mathrm{sp}}(550)$, say below $25 \mathrm{Mm}^{-1}$, are within spring, autumn (and summer) periods, with the corresponding monthly median values of $\alpha$ having a tendency to be lower, ranging between 1.0 and 1.5. 
Table 4. Values of scattering coefficient and Ångström exponent obtained for long-term measurements performed at different sites.

\begin{tabular}{lll}
\hline Place & $\sigma_{\mathrm{sp}}$ and $\alpha$ & Author \\
\hline Granada, Spain & $\sigma_{\mathrm{sp}}(550)=60 \mathrm{Mm}^{-1}$ and $\alpha=1.5$ & Lyamany et al. (2009) \\
Toulon, France & $\sigma_{\mathrm{sp}}(525)=60 \mathrm{Mm}^{-1}$ & Saha et al. (2008) \\
Northern Greece & $\sigma_{\mathrm{sp}}(550)=65 \mathrm{Mm}^{-1}$ and $\alpha=1.5$ & $\begin{array}{l}\text { Gerasopoulos et al. (2003) } \\
\text { Derimian et al. (2006) }\end{array}$ \\
$\begin{array}{l}\text { Israel } \\
\text { Remote site in the }\end{array}$ & $\begin{array}{l}\sigma_{\mathrm{sp}}(545)=60 \mathrm{Mm}^{-1} \\
\text { average (median) } \sigma_{\mathrm{sp}}(550)=87\end{array}$ & Andreae et al. (2002) \\
$\begin{array}{l}\text { Negev desert } \\
\text { Remote areas of }\end{array}$ & $(75) \mathrm{Mm}^{-1}$ and $\alpha=1.4(1.5)$ & \\
Greece and Turkey & $\sigma_{\mathrm{sp}}(532)=50 \mathrm{Mm}^{-1}$ and $45 \mathrm{Mm}^{-1}$ & Vrekoussis et al. (2005) \\
Hungary & $\sigma_{\mathrm{sp}}(530)=60 \mathrm{Mm}^{-1}$ & \\
This work & average $(\operatorname{median}) \sigma_{\mathrm{sp}}(550)=42.5$ & Molnár and Mészáros (2001) \\
& $(29.9) \mathrm{Mm}^{-1}$ and $\alpha=1.4(1.5)$ & \\
\hline
\end{tabular}

Table 5a. Basic statistical properties of $\sigma_{\mathrm{sp}}(550)$ organized for each month and season between 2002 and 2008.

\begin{tabular}{lllllllllll}
\hline \multicolumn{8}{c}{$\sigma_{\text {sp }}(550)\left(\mathrm{Mm}^{-1}\right)$} \\
Month & N & \multirow{2}{*}{ Season } & \multicolumn{2}{c}{ Median } & \multicolumn{2}{c}{ Mean } & & SD & P5 & P95 \\
\hline Dec & 4440 & & 34.4 & & 43.9 & & 33.3 & & 9.9 & 109.0 \\
Jan & 2799 & \multirow{2}{*}{ winter } & 49.9 & 40.2 & 64.1 & 53.5 & 52.7 & 46.1 & 13.8 & 163.3 \\
Feb & 2741 & & 42.7 & & 58.2 & & 52.9 & & 9.2 & 152.1 \\
Mar & 4191 & & 30 & & 39.3 & & 31.6 & & 10.7 & 94.2 \\
Apr & 4774 & \multirow{2}{*}{ spring } & 25.3 & 26.1 & 33.8 & 34.7 & 26.5 & 27.1 & 10.1 & 89.9 \\
May & 5002 & & 24.4 & & 31.7 & & 22.3 & & 10.7 & 78.7 \\
Jun & 4763 & & 34.4 & & 43.7 & & 30.5 & & 12.1 & 99.7 \\
Jul & 4493 & \multirow{2}{*}{ summer } & 32.7 & 32.8 & 43.8 & 47.1 & 38.9 & 66.3 & 10.4 & 111.8 \\
Aug & 3376 & & 31.3 & & 56.1 & & 114.0 & & 9.6 & 147.1 \\
Sep & 3391 & & 27.5 & & 36.9 & & 28.7 & & 9.4 & 92.7 \\
Oct & 3567 & \multirow{2}{*}{ autumn } & 24.3 & 26.8 & 32.9 & 36.9 & 27.2 & 30.6 & 8.4 & 87.6 \\
Nov & 3523 & & 28.7 & & 40.8 & & 34.9 & & 9.6 & 109.8 \\
\hline
\end{tabular}

The facts, described above, are in agreement with the pattern exhibited by the yearly cycles shown in Fig. 4. $\sigma_{\mathrm{sp}}(550)$ displays a bimodal pattern with peaks in winter and summer (Fig. 4a and b) and with the former peak being more prominent. The winter maximum is achieved in January for both the median and mean value $\left(50 \mathrm{Mm}^{-1}\right.$ and $64 \mathrm{Mm}^{-1}$, respectively); in summer the median is higher in June $\left(34 \mathrm{Mm}^{-1}\right)$ while the mean has its maximum in $\mathrm{Au}-$ gust $\left(56 \mathrm{Mm}^{-1}\right)$. This is caused, to a large extent, by occasional increases in the aerosol load due to the forest fires. The Ångström exponent, exhibited in Fig. 4c and d, follows a rather similar behaviour and a reasonable positive correlation between monthly median $\sigma_{\mathrm{sp}}(550)$ and $\alpha$ was found $\left(R^{2}=0.52\right)$, as shown in Fig. 5. However, no correlation was found for the hourly values because for small timescales the variability of these two quantities of different nature dominates, even if at larger timescales an overall tendency is revealed. The maximum value of the monthly median $\alpha$ is also found in January (1.8) and a second one in both July and August (1.5). This means that the increase in the aerosol load is mainly associated with the enhancement of particles in the sub-micrometer range, either with anthropogenic origin or forest fires' smoke occurring in the summer season. The increase of $\sigma_{\mathrm{sp}}(550)$ in the winter period should result from the combination of local traffic and increased emissions from heating sources (mainly wood burning) and pollution transported to the site. All these reasons are amplified by a decrease in boundary layer thickness due to the lower atmospheric temperatures at the surface during winter, thus, reducing atmospheric convection and consequently pollution dilution. In summer, the forest fires are greatly responsible for the large input of particles detected at the site (Elias et al., 2006; Pereira et al., 2008) and account for major increase in the aerosol scattering coefficients. The most intense smoke plumes were observed in August 2003 and particularly in August 2005 when hourly values of $\sigma_{\mathrm{sp}}(550)$ as high as $2000 \mathrm{Mm}^{-1}$ were measured. These two summer periods were the ones with the largest burnt areas ever recorded in Portugal (Autoridade Florestal Nacional, 2009). These facts are reflected in the mean $\sigma_{\mathrm{sp}}(550)$ peak value observed in 
Table 5b. Basic statistical properties of $\alpha$ organized for each month and season between 2002 and 2008.

\begin{tabular}{lllllllllll}
\hline \multicolumn{1}{c}{ Ångström exponent } \\
\hline Month & N & \multirow{2}{*}{ Season } & \multicolumn{2}{c}{ Median } & \multicolumn{2}{c}{ Mean } & SD & P5 & P95 \\
\hline Dec & 4440 & & 1.8 & 1.6 & & 0.5 & & & 0.7 & 2.2 \\
Jan & 2799 & \multirow{2}{*}{ winter } & 1.8 & 1.7 & 1.7 & 1.6 & 0.4 & 0.5 & 1.0 & 2.2 \\
Feb & 2741 & & 1.5 & & 1.5 & & 0.5 & & 0.5 & 2.2 \\
Mar & 4191 & & 1.3 & & 1.2 & & 0.5 & & 0.3 & 2.0 \\
Apr & 4774 & \multirow{2}{*}{ spring } & 1.4 & 1.3 & 1.3 & 1.2 & 0.5 & 0.5 & 0.3 & 1.9 \\
May & 5002 & & 1.3 & & 1.2 & & 0.4 & & 0.4 & 1.9 \\
Jun & 4763 & & 1.4 & & 1.4 & & 0.3 & & 0.8 & 1.9 \\
Jul & 4493 & \multirow{2}{*}{ summer } & 1.5 & 1.5 & 1.4 & 1.4 & 0.4 & 0.4 & 0.7 & 1.9 \\
Aug & 3376 & & 1.5 & & 1.4 & & 0.4 & & 0.6 & 2.0 \\
Sep & 3391 & & 1.4 & & 1.3 & & 0.5 & & 0.4 & 2.0 \\
Oct & 3567 & \multirow{2}{*}{ autumn } & 1.4 & 1.4 & 1.3 & 1.4 & 0.6 & 0.5 & 0.2 & 2.0 \\
Nov & 3523 & & 1.5 & & 1.5 & & 0.5 & & 0.6 & 2.1
\end{tabular}

Table 5c. Basic statistical properties of $\sigma_{\text {bsp }}(550)$ organized for each month and season between 2002 and 2008.

\begin{tabular}{lllllllllll}
\hline \multicolumn{1}{c}{$\sigma_{\text {bsp }}(550)\left(\mathrm{Mm}^{-1}\right)$} \\
Month & $\mathrm{N}$ & Season & \multicolumn{1}{c}{ Median } & Mean & & SD & P5 & P95 \\
\hline Dec & 4440 & & 5.2 & & 6.3 & & 4.7 & & 1.5 & 15.1 \\
Jan & 2799 & \multirow{2}{*}{ winter } & 6.8 & 5.6 & 8.5 & 7.3 & 6.9 & 6.0 & 2.2 & 20.6 \\
Feb & 2741 & & 5.7 & & 7.5 & & 6.5 & & 1.4 & 18.5 \\
Mar & 4191 & & 4.3 & & 5.2 & & 3.9 & & 1.7 & 11.4 \\
Apr & 4774 & \multirow{2}{*}{ spring } & 3.7 & 3.8 & 4.5 & 4.6 & 2.8 & 3.1 & 1.5 & 10.5 \\
May & 5002 & & 3.5 & & 4.2 & & 2.4 & & 1.6 & 9.1 \\
Jun & 4763 & & 4.8 & & 5.5 & & 3.1 & & 1.9 & 11.0 \\
Jul & 4493 & \multirow{2}{*}{ summer } & 4.7 & 4.8 & 5.8 & 6.1 & 4.3 & 8.1 & 1.6 & 12.8 \\
Aug & 3376 & & 4.7 & & 7.6 & & 14.3 & & 1.6 & 18.3 \\
Sep & 3391 & & & & 4.9 & & 3.0 & & 1.5 & 10.7 \\
Oct & 3567 & \multirow{2}{*}{ autumn } & 3.6 & 4.1 & 4.5 & 5.1 & 3.3 & 3.7 & 1.3 & 10.8 \\
Nov & 3523 & & 4.4 & & 5.8 & & 4.5 & & 1.5 & 14.6 \\
\hline
\end{tabular}

August which appears in Fig. 4a. The strong decrease in the number of forest fires and their intensity in 2007 and 2008 summers is perceptible in the $\sigma_{\mathrm{sp}}(550)$ values of Fig. 3a, as no significant peaks are visible in these periods; this led, for example, to a large difference in the monthly average and median values of $\sigma_{\mathrm{sp}}(550)$ between August 2005 (respectively $92 \mathrm{Mm}^{-1}$ and $39 \mathrm{Mm}^{-1}$ ) and August 2008 (respectively $28 \mathrm{Mm}^{-1}$ and $24 \mathrm{Mm}^{-1}$ ).

Also, the difference in the Ångström exponent between the winter and summer months is substantial, with monthly medians being in the range of 1.5-1.8 and 1.4-1.5, respectively; this is expected to be related to the dryness of the soils and well-developed convection in the boundary layer during the summer season which enhances the presence of coarse soil material in the atmosphere. In contrast, during winter (typical rainy season) the relative amount of coarse material is expected to be much lower, while the introduction of submicrometer particles from wood combustion in the atmosphere in winter is more regular than the transient transport of smoke to Évora. Lyamani et al. (2008, 2010) and Saha et al. (2008) also reported annual cycles characterised by higher values of scattering coefficient in winter but with magnitudes significantly higher than ours (average $\sigma_{\mathrm{sp}}(550)=84-$ $90 \mathrm{Mm}^{-1}$ and $\alpha=1.8$ and average $\sigma_{\mathrm{sp}}(550)>90 \mathrm{Mm}^{-1}$, respectively). In spite of the large difference in terms of aerosol concentration between Évora and Granada (and Toulon), in winter, the difference between the values of $\alpha$ are less important due likely to similarities in the origin of aerosol particles.

No trend is evident for the measured quantities between 2002 and 2008. In 2008, the noticeable decrease in the time series of annual values of both $\sigma_{\mathrm{sp}}(550)$ and $\sigma_{\mathrm{bsp}}(550)$ can be explained by the lack of data during 2008 winter period and the absence of forest fires during the following 2008 summer.

\subsubsection{Daily cycle}

Daily patterns of $\sigma_{\mathrm{sp}}(550)$ and $\alpha$ values are analysed in this section (see Fig. 6). Median values instead of average values are used in order to minimize external influences and extreme 

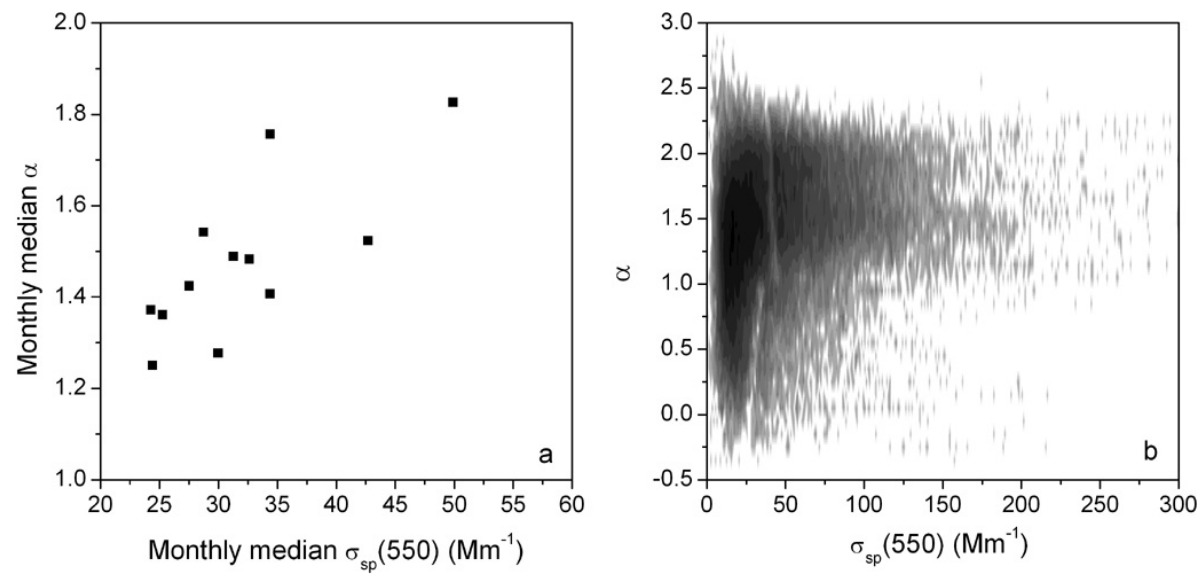

Fig. 5. Scatter plot with the monthly median $\alpha$ as a function of the monthly median $\sigma_{\mathrm{sp}}(550)$ (a) and scatter plot with the density of measurements of hourly values of the same quantities (b).

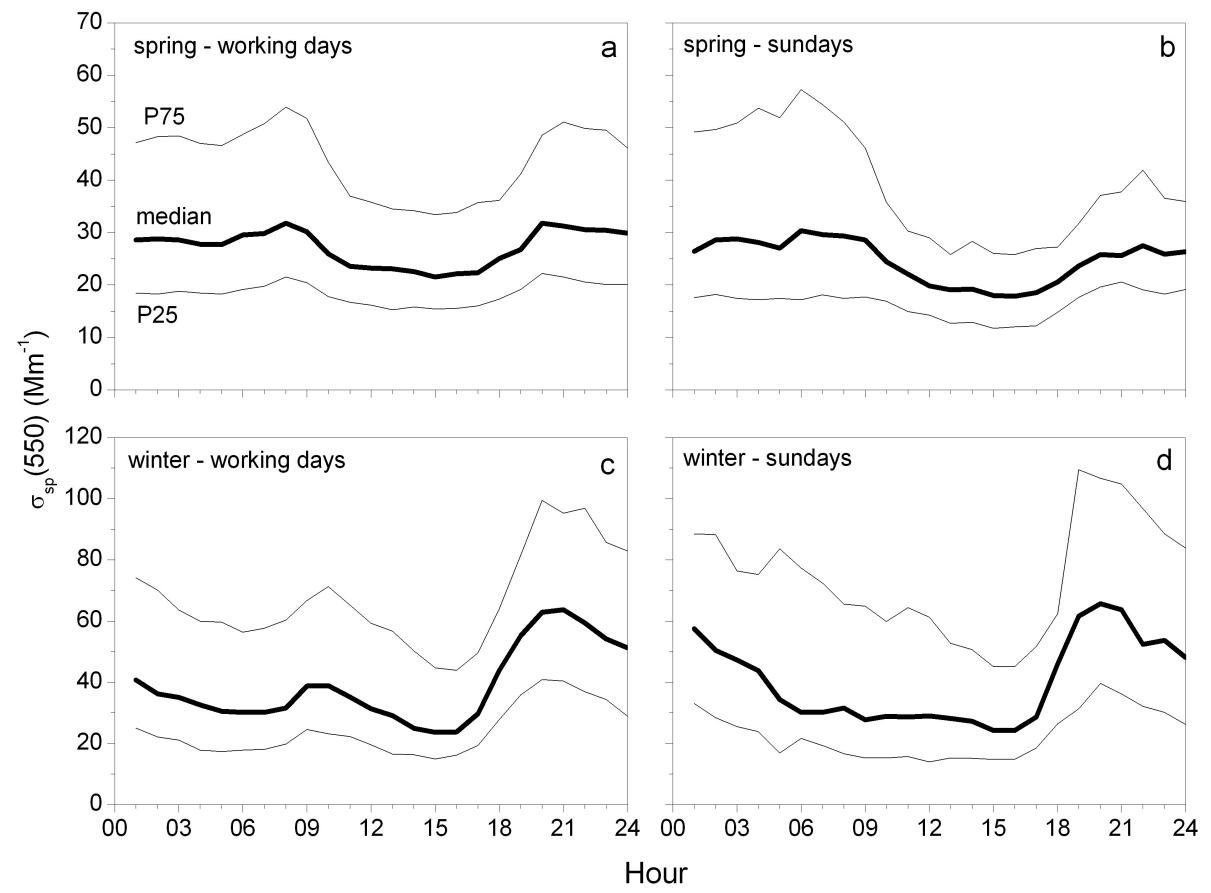

Fig. 6. Daily variation of median values of $\sigma_{\mathrm{sp}}(550)$ for (a) spring working days and (b) Sundays and (c) winter working days and (d) Sundays. The respective quartiles are also shown.

events, so local aerosol features can emerge. We focus on winter and spring periods because they showed rather distinct statistical properties, as it was exposed in the previous section, and may be somewhat representative of colder and less colder (warmer) periods. The summer period was not considered since it was already revealed to be frequently contaminated by (at least) forest fires smoke plumes transported from other regions. Also a distinction is made between the daily variations during week days (Monday to Friday, normal working days), and Sunday (non-work day when anthropogenic activities are significantly reduced).
A daily pattern was found for $\sigma_{\mathrm{sp}}(550)$, with morning and late afternoon peaks, regarding the week days. This behaviour is characteristic of urban areas (Lyamani et al., 2008; Andreae et al., 2008). The P25 and P75 curves, also displayed in Fig. 6, show the same features and indicate consistency of this pattern regardless of the day-to-day variability. The morning peak (Fig. 6a and c) is closely related to the enhanced traffic activity during morning rush hour and, therefore, is much less evident on Sundays (Fig. 6b and d), in particular, during winter when typically the city is less active, during the morning time. The boundary layer development 
along the day, together with the increase in convection, provides the conditions for particle dilution within a larger volume of air. This results in the decrease of $\sigma_{\mathrm{sp}}(550)$ at the surface during the afternoon and a minimum around 15:00 is observed. In the late afternoon the combination of increased anthropogenic activity, due to traffic, and decrease of the boundary layer thickness lead again to the increase in $\sigma_{\mathrm{sp}}(550)$.

The general features described above also show significant seasonal differences. Important differences between colder and warmer periods are related with boundary layer dynamics and additional anthropogenic activity associated with wood burning for heating purposes, besides the usual particle production by traffic activity during the year. These differences are visible in the patterns observed in Fig. 6a and c. In spring, both morning and late afternoon peaks of $\sigma_{\mathrm{sp}}(550)$ values have similar magnitudes (about $32 \mathrm{Mm}^{-1}$ ), however, in winter the morning peak is not only considerably higher $\left(39 \mathrm{Mm}^{-1}\right)$ than in spring, but also a large difference for the late afternoon peak is now visible. The magnitude of this second peak $\left(64 \mathrm{Mm}^{-1}\right)$ represents a twofold increase relative to spring conditions and emphasizes the importance of wood burning, which typically begins in the late afternoon and is likely the main reason for the difference (by a factor of 1.6) to the morning peak in winter.

In spite of higher $\sigma_{\mathrm{sp}}(550)$ values in winter, at all times, two periods of the day with minimum values (early morning, 05:00-06:00 and middle afternoon, around 15:00) present the lowest differences in $\sigma_{\mathrm{sp}}(550)$ between winter and spring $\left(<3 \mathrm{Mm}^{-1}\right)$. Moreover, the absolute minimum is always achieved in the middle afternoon. On the one hand, in both of these periods the source activities are reduced while the particle removal processes are always active; on the other hand, the dilution of particles is enhanced in the developed boundary layer which occurs in the afternoon, after the solar heating of the surface. Both these features contribute to the decrease in the particle load, independently of the season and probably explain the similarity of $\sigma_{\mathrm{sp}}(550)$ values in these hours of the day.

Regarding the daily variation of the Ångström exponent, two main differences were found: firstly, the magnitude of $\alpha(1.1-1.4)$ in spring is always lower than in winter (1.5$1.9)$; secondly, in winter the correlation between $\sigma_{\mathrm{sp}}(550)$ and $\alpha$ appears to be consistent; this validates the connection between the aerosol load and its anthropogenic origin. In contrast, during spring the values of $\alpha$ reveal no particular trend (as suggested by the lack of correlation between $\sigma_{\mathrm{sp}}(550)$ and $\left.\alpha\right)$.

\subsection{Influence of air mass history on the aerosol properties}

Airborne particles that are detected at a certain site may have been produced locally or transported from elsewhere. In this section, the measured aerosol optical properties are associ- ated to back trajectories paths in order to infer, in a simple way, on the influence of the emission sources in the aerosol load and type over Évora, at the surface. Five day back trajectories arriving at the monitoring site, at $500 \mathrm{~m}$ a.s.l. (200 m a.g.1.), were computed at 12:00 UTC for each day. The height of $500 \mathrm{~m}$ was chosen to represent the air masses sampled by the nephelometer. The hourly averages (between 12:00 and 13:00) of measured quantities were used. By doing so, temporal agreement between the trajectories arrival and the measured aerosol optical properties is guaranteed, the local aerosol influence is reduced and, hence, the possible influence of long-range transport is enhanced. In spite of their complexity and variability, the trajectories were classified into five different types.

Trajectories originating over the Atlantic Ocean were separated into two different types according to the time they travelled over the continent. Therefore, two levels of continental influence were distinguished. About half of the trajectories from the Atlantic were observed to arrive at Évora after a significant path over the Iberian Peninsula; a period of more than one day over land was considered for classifying these back trajectories as MIB (maritime and Iberian Peninsula) as opposed to the maritime trajectories, M. The trajectories were classified as maritime if they remained less than $24 \mathrm{~h}$ over the continent (usually by arriving at Évora through the western Portuguese coast). The purpose of the separation between M and MIB trajectories was to study the influence of the air masses ageing over the Iberian Peninsula in the measured aerosol properties at the site. The average resident times over the Iberian Peninsula were 10 and $46 \mathrm{~h}$ for $\mathrm{M}$ and MIB trajectories, respectively. The back trajectories classification also included the influence of Europe (EU), for air masses from the European continent (from Britain, Central Europe to the northern coasts of the Mediterranean Sea), Africa (AF), for air masses originated in the African continent and the Iberian Peninsula (IB) itself, for air masses originated and staying mainly within the Spanish and Portuguese territories. Figure 7 shows the features mentioned above, including the frequency of occurrence that a trajectory passes over a certain geographic area, as well as the average path for each set of trajectories. The sector with the largest influence over the measurements site is the Atlantic area ( $\mathrm{M}$ and MIB types), with accumulated $70 \%$ of occurrence. The European sector contributes with $21 \%$ while both the African and Iberian sectors contribute with $9 \%$ of occurrence.

Figure 8 shows the relative frequency distributions of $\sigma_{\mathrm{sp}}(550), \alpha$ and $\sigma_{\mathrm{bsp}}(550)$ values according to the different trajectories classification while the correspondent average and median values are shown in Table 6 .

The difference in the respective aerosol properties seems to validate the separation between M and MIB trajectories as statistically significant differences (at the 0.05 level) were found according to hypothesis tests. The values of $\sigma_{\mathrm{sp}}(550)$ are systematically low (and narrow distributed, essentially below $40 \mathrm{Mm}^{-1}$ ) for $\mathrm{M}$ trajectories, but as soon 

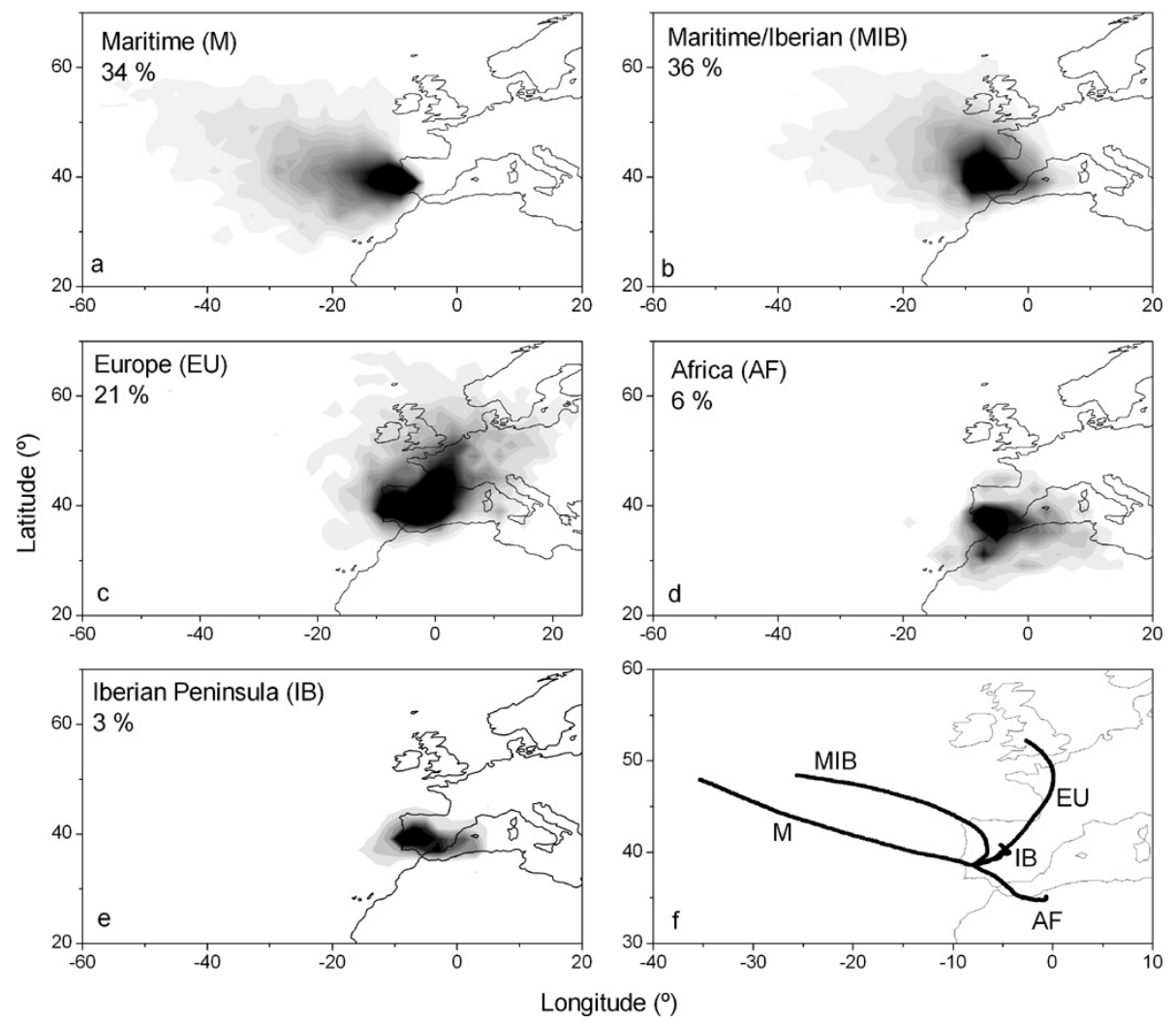

Fig. 7. Probability density for back trajectories at Évora (a-e) and average path (f) for each trajectory category. The frequency of occurrence for each trajectory category is also shown.

Table 6. Average and median values of $\sigma_{\mathrm{sp}}(550), \sigma_{\mathrm{bsp}}(550)$ and $\alpha$ for each trajectory type. The frequency of occurrence for each type is also shown.

\begin{tabular}{lrrr}
\hline $\begin{array}{l}\text { Trajectory class } \\
\text { frequency of occurrence) }\end{array}$ & $\begin{array}{r}\text { Mean/Median } \\
\sigma_{\mathrm{sp}}(550)\left(\mathrm{Mm}^{-1}\right)\end{array}$ & $\begin{array}{r}\text { Mean/Median } \\
\sigma_{\mathrm{bsp}}(550)\left(\mathrm{Mm}^{-1}\right)\end{array}$ & $\begin{array}{r}\text { Mean/Median } \\
\alpha\end{array}$ \\
\hline Maritime M (34\%) & $20.5 / 16.8$ & $2.9 / 2.5$ & $1.2 / 1.2$ \\
MaritimeIB MIB (36\%) & $35.4 / 26.5$ & $4.9 / 4.1$ & $1.6 / 1.6$ \\
Europe EU (21\%) & $40.0 / 32.7$ & $5.4 / 4.7$ & $1.6 / 1.7$ \\
Iberian IB (3\%) & $59.1 / 43.1$ & $7.2 / 6.1$ & $1.6 / 1.6$ \\
African AF (6\%) & $58.7 / 49.5$ & $7.4 / 6.6$ & $1.3 / 1.4$ \\
\hline
\end{tabular}

as the air masses increase their continental influence (i.e., become MIB) a large portion of $\sigma_{\mathrm{sp}}(550)$ values increase considerably. The Ångström exponent distribution is also shifted towards larger values and values lower than 1 become much less frequent. This simultaneous enhancement both in $\sigma_{\mathrm{sp}}(550)$ and $\alpha$ points up that the increase in the aerosol load is related to the input of fine particles with Iberian origin (presumably in conjunction with the gradual deposition and loss of influence of maritime coarse particles). Also the similarity between the average/median values of $\alpha$ for MIB and for EU and IB trajectories (1.6-1.7) and the increase in $\sigma_{\mathrm{sp}}(550)$ for EU and IB trajectories (from $26.5 \mathrm{Mm}^{-1}$ for MIB to 32.7 and $43.1 \mathrm{Mm}^{-1}$ ) corroborates the previous statements. Re-circulations of the air masses within the Iberian
Peninsula, related with low advection conditions, induce the accumulation of pollutants and likely validates the higher values of $\sigma_{\mathrm{sp}}(550)$ which characterise the IB regime. Concerning the African trajectories, they are also characterised by high values of $\sigma_{\mathrm{sp}}(550)$. The frequency distribution of $\alpha$ includes again an important contribution of values below 1.0, which is consistent with the influence of coarse dust particles, however, high $\alpha$ values, well above 1.0, still dominate (median $=1.4)$ and no correlation is observed between the values of $\sigma_{\mathrm{sp}}(550)$ and $\alpha$; the highest values of $\sigma_{\mathrm{sp}}(550)$ correspond to values of $\alpha$ ranging from 0 up to 2 . This means that when trajectories have African origin desert dust particles usually do not dominate the aerosol at the ground or are not even present; in that case the higher aerosol loads are presumably 

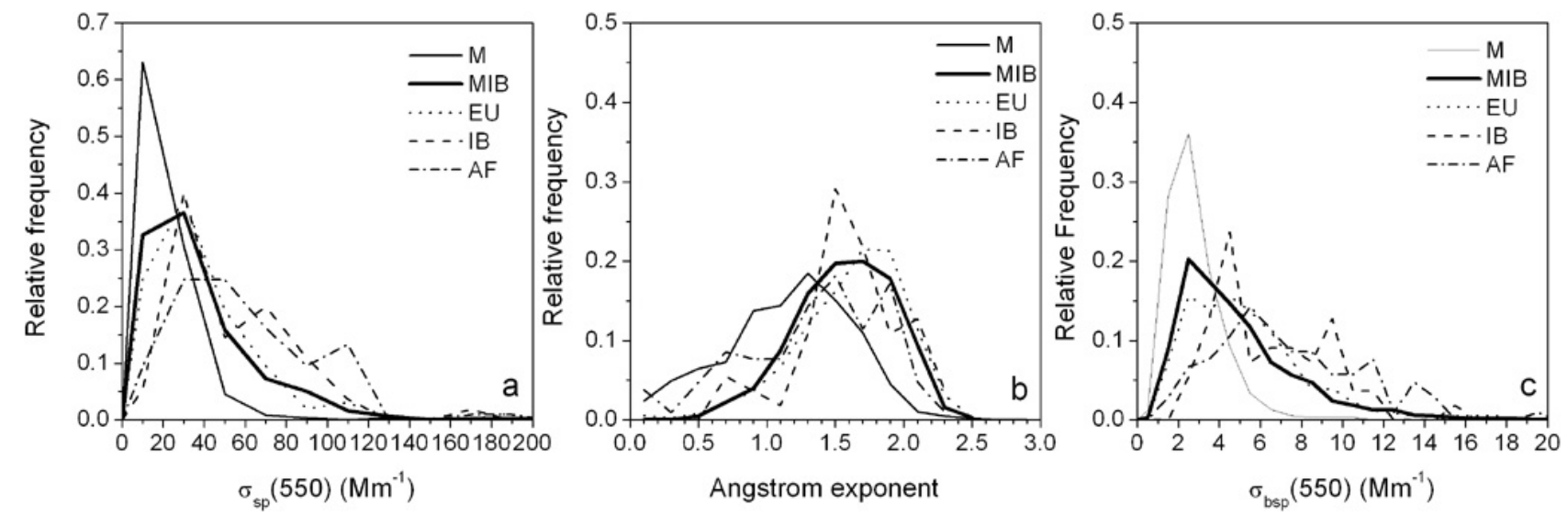

Fig. 8. Relative frequency distributions of $(\mathbf{a}) \sigma_{\mathrm{sp}}(550)\left(\right.$ bin size $\left.=20 \mathrm{Mm}^{-1}\right),(\mathbf{b}) \alpha($ bin size $=0.2)$ and $(\mathbf{c}) \sigma_{\mathrm{sp}}(550)\left(\mathrm{bin} \operatorname{size}=1 \mathrm{Mm}{ }^{-1}\right)$ for each trajectory type.

caused by anthropogenic particles. This is in agreement with the long-range transport of mineral dust occurring frequently at high altitudes, as previously noticed by other authors (Elias et al., 2006; Derimian et al., 2006).

\section{Summary and conclusions}

Aerosol scattering properties, near the surface, were measured over a period of seven years (2002-2008) at Évora, Portugal.

The average (and median) $\sigma_{\mathrm{sp}}(550), \sigma_{\mathrm{bsp}}(550)$ and $\alpha$ were found to be $42.5 \mathrm{Mm}^{-1}\left(29.9 \mathrm{Mm}^{-1}\right), 5.9 \mathrm{Mm}^{-1}$ $\left(4.4 \mathrm{Mm}^{-1}\right)$ and 1.4 (1.5), respectively. These values mean that, in general, the aerosol load can be considered as moderate with the aerosol population being dominated by submicrometer particles, in particular, during winter when the average $\alpha$ was maximum (1.6).

Both seasonal and daily cycles were shown, which were related to local features (city traffic and domestic heating, the latter during winter) as well as the transport of particles from elsewhere. The average values of the scattering coefficient, at the wavelength of $550 \mathrm{~nm}$, for summer and winter $\left(47\right.$ and $\left.54 \mathrm{Mm}^{-1}\right)$, represent a significant increase in the aerosol particle concentration, when compared with spring and fall ( 35 and $37 \mathrm{Mm}^{-1}$ ); the simultaneous increase in $\alpha$ is consistent with the input of fine particles from anthropogenic origin in winter and forest fires in summer. The daily variation of the scattering coefficient, with morning and afternoon peaks (more prominent during working days), is related to the local anthropogenic activities, besides the boundary layer dynamics.

The measured optical properties were shown to be dependent on the influence of different air masses. When the site was under the influence of air masses from Atlantic region low particle loads (low scattering coefficients) were ob- served, but as the influence of the continent (Iberia Peninsula) increased, the aerosol particle load was also observed to increase, as well as the Ångström exponent, approaching the features observed during European air masses influence. During African air masses influence, high values of the scattering coefficients were also observed, but with smaller Ångström exponent due to the contribution of dust particles, however, in general, the scattering was still dominated by fine particles indicating that either dust at the surface was not so frequent or that it was mixed with anthropogenic pollution.

Acknowledgements. The authors gratefully acknowledge the NOAA Air Resources Laboratory (ARL) for the provision of the HYSPLIT transport and dispersion model and/or READY website (http://www.arl.noaa.gov/ready.php) used in this publication.

This work was supported by FCT (Science and Technology Foundation) under the grants SFRH/BPD/29687/2006 and SFRH/BD/29008/2006.

Edited by: R. Krejci

\section{References}

Anderson, T. L. and Ogren, J. A.: Determining aerosol radiative properties using the TSI 3563 integrating nephelometer, Aerosol. Sci. Tech., 29, 57-69, 1998.

Andreae, T. W., Andreae, M. M., Ichoku, C., Maenhaut, W., Cafmeyer, J., Karniely, A., and Orlovsky, L.: Light scattering by dust and anthropogenic aerosol at a remote site in the Negev desert, Israel, J. Geophys. Res., 107(D2), 4008, doi:10.1029/2001JD900252, 2002.

Ansmann, A., Wagner, F., Müller, D., Althausen, D., Herber, A., von Hoyningen-Huene, W., and Wandinger, U.: European pollution outbreaks during ACE 2: Optical particle properties inferred from multiwavelength lidar and star-Sun photometry, J. Geophys. Res., 107(D15), 4259, doi:10.1029/2001JD001109, 2002. 
Artiñano, B., Querol, X., Salvador, P., Rodríguez, S., Alonso, D. G., and Alastruey, A.: Assessment of airborne particulate levels in Spain in relation to the new EU-directive, Atmos. Environ., 35(Suppl. 1), S43-S53, 2001.

Autoridade Florestal Nacional: Relatório - Áreas ardidas e ocorrências em 2008, available at: http: //www.afn.min-agricultura.pt/portal/dudf/relatorios/2008/ relatorio-final-2008, 2009.

Carrico, C. M., Rood, M. J., and Ogren, J. A.: Aerosol light scattering properties at Cape Grim, Tasmania, during the First Aerosol Characterization Experiment (ACE 1), J. Geophys. Res., 103(D13), 16565-16574, 1998.

Carrico, C. M., Rood, M. J., Ogren, J. A., Neusüß, C., Wiedensohler, A., and Hintzenberg, J.: Aerosol optical properties at Sagres, Portugal, during ACE-2, Tellus, Ser. B, 52, 694-715, 2000.

Carrico, C. M., Kus, P., Rood, M. J., Quinn, P. K., and Bates, T. S.: Mixtures of pollution, dust, sea salt, and volcanic aerosol during ACE-Asia: Radiative properties as a function of relative humidity, J. Geophys. Res., 108(D23), 8650, doi:10.1029/2003JD003405, 2003.

Deacon, A. R., Derwent, R. G., Harrison, R. M., Middleton, D. R., and Moorcroft, S.L: Analysis and interpretation of measurements of suspended particulate matter at urban background sites in the United Kingdom, Sci. Total Environ., 203, 17-36, 1997.

Delene, D. J. and Ogren, J. A.: Variability of aerosol optical properties at four North American surface monitoring sites, J. Atmos. Sci., 59, 1135-1150, 2002.

Derimian, Y., Karnieli, A., Kaufmann, Y. J., Andreae, M. O., Andreae, T. W., Dubovik, O., Maenhaut, W., Koren, I., and Holben, B. N.: Dust and pollution aerosols over the Negev desert, Israel: Properties, transport and radiative effect, J. Geophys. Res., 111, D05205, 15 doi:10.1029/2005JD006549, 2006.

Doherty, S. J., Quinn, P. K., Jefferson, A., Carrico, C. M., Anderson, T. L., and Hegg, D.: A comparison and summary of aerosol optical properties as observed in situ from aircraft, ship, and land during ACE-Asia, J. Geophys. Res., 110, D04201, doi:10.1029/2004JD004964, 2005.

Draxler, R. R. and Rolph, G. D.: HYSPLIT (Hybrid Single-Particle Lagrangian Integrated Trajectory) model access via NOAA ARL READY Website, NOAA Air Resources Lab., Silver Spring, MD, available at: http://www.arl.noaa.gov/ready/hysplit4.html, 2003.

Elias, T., Silva, A. M., Belo, N., Pereira, S., Formenti, P., Helas, G., and Wagner, F.: Aerosol extinction in a remote continental region of the Iberian Peninsula during summer, J. Geophys. Res., 111, D14204, doi:10.1029/2005JD006610, 2006.

Fierz-Schmidhauser, R., Zieger, P., Weingartner, E., Gysel, M., DeCarlo, P. F., and Baltensperger, U.: Aerosol light scattering at high relative humidity at a high alpine site (Jungfraujoch), European Aerosol Conference, Abstract T047A07, 2009.

Freitas, C.: Synoptic and Mesoscale Meteorological Patterns During PM Events in Lisbon Area, Master thesis, University of Évora, Portugal, 189 pp., 2006.

Gerasopoulos, E., Andreae, M. O., Zerefos, C. S., Andreae, T. W., Balis, D., Formenti, P., Merlet, P., Amiridis, V., and Papastefanou, C.: Climatological aspects of aerosol optical properties in Northern Greece, Atmos. Chem. Phys., 3, 2025-2041, doi:10.5194/acp-3-2025-2003, 2003.
Horvath, H.: Spectral extinction coefficients of rural aerosol in southern Italy - a case study of cause and effect of variability of atmospheric aerosol, J. Aerosol. Sci., 27(3), 437-453, 1996.

Koloutsou-Vakakis, S., Carrico, C. M., Kus, P., Rood, M. J., Li, Z., Shrestha, R., Ogren, J. A., Chow, J. C., and Watson, J. G.: Aerosol properties at a midlatitude Northern Hemisphere continental site, J. Geophys. Res., 106(D3), 3019-3032, 2001.

Kotchenruther, R. A., Hobbs, P. V., and Hegg, D. A.: Humidification factors for atmospheric aerosols off the mid-Atlantic coast of the United States, J. Geophys. Res., 104(D2), 2239-2251, 1999.

Lyamani, H., Olmo, F. J., and Alados-Arboledas, L.: Light scattering and absorption properties of aerosol particles in the urban environment of Granada, Spain, Atmos. Environ., 42, 2630-2642, 2008.

Lyamani, H., Olmo, F. J., and Alados-Arboledas, L.: Physical and optical properties of aerosols over an urban location in Spain: seasonal and diurnal variability, Atmos. Chem. Phys., 10, 239 254, doi:10.5194/acp-10-239-2010, 2010.

Magi, B. I. and Hobbs, P. V.: Effects of humidity on aerosols in southern Africa during the biomass burning season, J. Geophys. Res., 108(D13), 8495, doi:10.1029/2002JD002144, 2003.

Molnár, A. and Mészáros, E.: On the relation between the size and chemical composition of aerosol particles and their optical properties, Atmos. Environ., 35, 5053-5058, 2001.

Müller, D., Ansmann, A., Wagner, F., Franke, K., and Althausen, D.: European pollution outbreaks during ACE 2: Microphysical particle properties and single-scattering albedo inferred from multiwavelength lidar observations, J. Geophys. Res., 107(D15), 4248, doi:10.1029/2001JD001110, 2002.

Pereira, S., Wagner, F., and Silva, A. M.: Scattering properties and mass concentration of local and long range transported aerosols over the south western Iberian Peninsula, Atmos. Environ., 42, 7623-7631, 2008

Quinn, P. K., Coffman, D. J., Bates, T. S., Miller, T. L., Johnson, J. E., Welton, E. J., Neusüss, C., Miller, M., and Sheridan, P. J.: Aerosol optical properties during INDOEX 1999: Means, variability, and controlling factors, J. Geophys. Res., 107(D19), 8020, doi:10.1029/2000JD000037, 2002.

Saha, A., Mallet, M., Roger, J. C., Dubuisson, P., Piazzola, J., and Despiau, S.: One year measurements of aerosol optical properties over an urban coastal site: Effect on local direct radiative forcing, Atmos. Res., 90, 195-202, 2008.

Sheridan, P. J., Delene, D. J., Ogren, J. A., Four years of continuous surface aerosol measurements from the Department of Energy's Atmospheric Radiation Measurement Program Southern Great Plains Cloud and Radiation Testbed site, J. Geophys. Res., 106(D18), 20735-20747, 2001.

Silva, A. M., Bugalho, M. L., Costa, M. J., von Hoyningen-Huene, W., Schmidt, T., Heintzenberg, J., and Henning, S.: Aerosol optical properties from columnar data during the second Aerosol Characterization Experiment on the south coast of Portugal, J. Geophys. Res., 107(D22), 4642, doi:10.1029/2002JD002196, 2002

Silva, A. M., João Costa, M., Elias, T., Formenti, P., Belo, N., and Pereira, S.: Ground based aerosol monitoring at Évora, Portugal, Global Change Newsletter, Issue No. 56, 6-9, December 2003.

Targino, A. C., Noone, K. J., Öström, E.: Airborne in situ characterization of dry aerosol optical properties in multi-source influenced marine region, Tellus 57B, (3), 247-260, 2005. 
Vrekoussis, M., Liakakou, E., Kocak, M., Oikonomou, K., Sciare, J., and Mihalopoulos, N: Seasonal variability of optical properties of aerosols in the eastern Mediterranean, Atmos. Environ., 39, 7083-7094, 2005.
Wagner, F., D. Bortoli, S. Pereira, M. J. Costa, A. M. Silva, B. Weinzierl, M. Esselborn, A., Petzold, K., Rasp, B., Heinold, and Tegen, I.: Properties of dust aerosol particles transported to Portugal from the Sahara desert, 61, B Tellus, 61B(1), 297-30, 2009. 